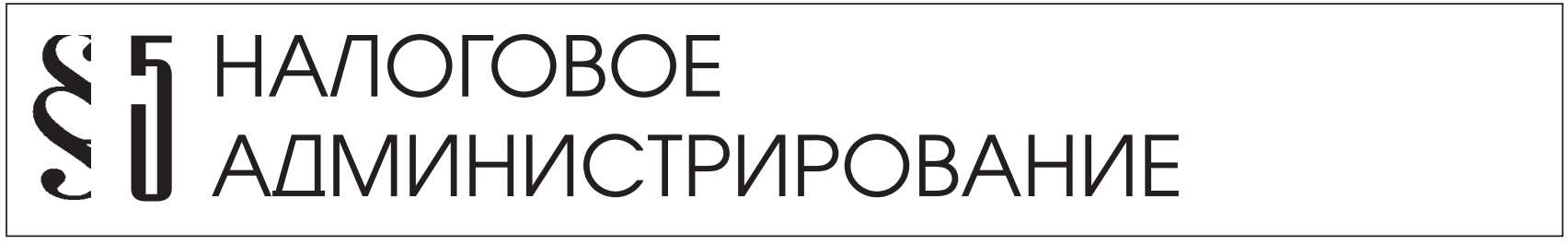

Надточий Е.В.

\title{
ИСТОРИЯ СТАНОВЛЕНИЯ И РАЗВИТИЯ СТРАТЕГИЧЕСКИХ ОРИЕНТИРОВ ГОСУДАРСТВЕННОЙ НАЛОГОВОЙ ПОЛИТИКИ
}

Аннотация: Исследование государственной налоговой политики в статье проведено исходя из положений ее органического единства с экономической и бюджетной политикой страны. Выявлена эволючия стратегических ориентиров налоговой политики с 988 по 2013 гг. Установлено, что в среднесрочной перспективе формирование фискального пространства государства будет происходить в условиях действующей совокупности стратегических ориентиров налоговой политики: 1) обеспечения наполняемости бюджетов; 2) оптимальной налоговой нагрузки хозяйствующих субъектов; 3) обеспечения модернизации экономики; 4) качественного налогового администрирования.

Ключевые слова: Налоги и налогообложение, экономика, политика, стратегия, тактика, ориентиры, приоритеты, меры, факторы, перспективы

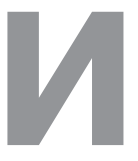

сследование налоговой политики государства исходит из положения ее органического единства с экономической и бюджетной политикой страны.

Мнения ученых о сущности экономической политики государства условно можно представить в виде несколько групп.

По мнению одних ученых, в частности И.В. Бережного ${ }^{1}$, Дж. М. Кейнса ${ }^{2}$, Р. Коуэна ${ }^{3}$,

\footnotetext{
${ }^{1}$ Бережной И.В. Государственная экономическая политика обеспечения конкуренции: уровни, проблемы, инструменты // Journal of Economic Regulation = Вопросы регулирования экономики. - 2010. - Т. 1. - № 1. - C. 23-32.

${ }^{2}$ Кейнс Дж. М. Общая теория занятости, процента и денег. - М.: Прогресс, 1978. - С 46.

${ }^{3}$ Коуэн Р. Зависимость от предшествующей траектории развития, причинная связь и экономическая политика // Terra Economicus. - 2004. - T. 2. - № 4. - C. 10-29.
}

Н.М. Розановой ${ }^{4}$, Ю.В. Яременко ческая политика призвана помочь рынку работать успешно. Так, Дж. М. Кейнс считает, что экономическая политика «выражает общественную волю, - это государственное регулирование, которое воздействует на такие независимые переменные, как склонность к потреблению, предельная эффективность капитала и норма процента, а через их посредство на занятость и на национальный доход» ${ }^{6}$.

\footnotetext{
${ }^{4}$ Розанова Н.M. Экономическая политика России и конкуренция: есть ли точки соприкосновения // Terra Economicus. - 2005. - T. 3. - № 1. - C. 43-61.

5 Яременко Ю.В. Экономический рост. Структурная политика // Проблемы прогнозирования. - 2001. № $1 .-$ C. 6-14.

${ }^{6}$ Кейнс Дж. М. Общая теория занятости, процента и денег. - М.: Прогресс, 1978. - С 46.
} 
По мнению других исследователей, например, в словаре Макмиллана ${ }^{7}$ (лондонская экономическая школа) или в работах В.В. Андросова ${ }^{8}$ экономическая политика рассматривается как поведение государства в отношении экономики для обеспечения оптимума благосостояния, выраженного в количественных макроэкономических показателях, достижимых в данных конкретных условиях.

Третья группа ученых, в частности А. И. Амосов ${ }^{9}$, А.В. Пашков ${ }^{10}$ под экономической политикой понимают выполнение в системе управления экономикой функции государства для обеспечения развития в условиях преобладания индикативного планирования и ограничения директивного бюджетными программами.

Четвертая группа исследователей, например С.А. Афонцев ${ }^{11}$, Е.А. Буланова ${ }^{12}$,

${ }^{7}$ Словарь современной экономической теории Макмиллана / под ред. Пирс В.А. - М.:, Инфра-М, 2003. - C. 574.

8 Андросов В.В. Экономическая политика государства: вопросы методологии // Социальноэкономические явления и процессы. - 2010. - № 2. - С. 8-11; Андросов В.В. Карпунина Е.К. Экономическая политика государства: значение национального российского менталитета // Социально-экономические явления и процессы. - 2010. - № 1. - C. 45-49.

${ }^{9}$ Амосов А.И. Промышленная политика и перелив капитала //Экономист. - 2004. - № 10. - С. 12-16.

${ }^{10}$ Пашков А.В. Экономическая политика: понятие и содержание // Исторические, философские, политические науки, культурология и искусствоведение. Вопросы теории и практики. - 2012. № 5-2. - C. 133-138.

${ }^{11}$ Афониев С.A. Теоретический анализ формирования экономической политики на национальных и международных политических рынках: автореф. ... д.э.н. - Москва, 2010. - С. 18.

${ }^{12}$ Буланова E.A. Политика и стратегия в механизме государственного регулирования социально-экономических процессов // Вестник Чувашского университета. -2006 - № 3. - С. 143-153.
В.Г. Лоскутов ${ }^{13}$ В. Ойкен ${ }^{14}$, Ф.Ф. Рыбаков ${ }^{15}$ рассматривают экономическую политику как воздействие на экономические процессы с целью обеспечения экономического развития. Так, В. Ойкен понимает под экономической политикой «совокупность государственных мер воздействия на экономические процессы. Решающая задача экономической политики состоит в создании условий, которые не приводят к возникновению опасных тенденций в экономике» ${ }^{16}$. С.А. Афонцев полагает, что «экономическая политика представляет собой взаимосвязанную систему долгосрочных и текущих целей экономического развития, которые определены государством. Она оказывает влияние на результаты, достигаемые экономическими субъектами и субъектами гражданского общества в реализации их интересов, и приводит к дальнейшей модификации их запросов в отношении экономической политики» ${ }^{17}$.

Рассмотрев, изложенный спектр мнений, думается, что мнение четвертой группы ученых о сущности экономической политики охватывает точки зрения предыдущих групп исследователей, поскольку экономическое развитие представляет собой

13 Лоскутов В.Г. Державная экономическая политика императивы выживаемости России как национального государства // Вестник Тамбовского университета. Серия: Гуманитарные науки. - 2010. T. 81. - № 1. - С. 9-14.

${ }^{14}$ Ойкен В. Основы национальной экономии: научное издание. - М.: Директ-Медиа, 2007. - С. 118.

${ }^{15}$ Рыбаков Ф.Ф. Экономическая политика: теоретические основы и опыт преподавания // Вестник СанктПетербургского университета. Серия 5: Экономика. - 2009. - № 1. - С. 144-150.

${ }^{16}$ Ойкен В. Основы национальной экономии: научное издание. - М.: Директ-Медиа, 2007. - С. 118.

${ }^{17}$ Афонцев С.А. Теоретический анализ формирования экономической политики на национальных и международных политических рынках: автореф. ... д.э.н. - Москва, 2010. - С. 18. 


\section{Налоги и налогообложение - №4(106) • 2013}

многоплановый процесс, охватывающий экономический рост, структурные сдвиги в экономике, координацию рыночного функционирования, повышение благосостояния населения и т.д.

Ядром обеспечения экономического развития государства являются централизованные денежные ресурсы страны, которые создаются и используются посредством государственной бюджетной политики.

В послании Президента Российской Федерации (далее - РФ) «О бюджетной политике на 2001 г.» отмечено, что «Бюджетная политика является ключевым звеном экономической политики государства и отражает все его финансовые отношения с общественными институтами и гражданами» ${ }^{18}$.

Большинство исследователей ${ }^{19}$ сходятся во мнении о том, что бюджетная политика направлена на мобилизацию централизованных финансовых ресурсов государства, их распределение и использование.

Следовательно, государственная налоговая политика (как важнейший инструмент мобилизации финансовых ресурсов) является одним из структурных компонентов бюджетной политики.

Подтверждением данного вывода является тот факт, что в основных направлениях бюджетной политики, утвержденных министерством финансов РФ (например,

18 Бюджетное послание Федеральному Собранию «О бюджетной политике на 2001 г.» 31 мая 2000 г. URL.: http://openbudget.karelia.ru/budposl_pres2001. html (дата обращения 25.04.2013).

19 См., например: Горшков А.А. Проблемы безопасности региональной бюджетной политики: научное издание. - Волгоград: Нижне-Волжское книжное издательство, 2002. - С. 7; Ковалева Т.М., Барулин $C . B$. Бюджет и бюджетная политика в РФ: научное издание. - М.: КНОРУС, 2006. - С. 32; Васильева М.В., Лукъянова А.В. Императивы бюджетной политики: региональный и муниципальный аспекты: монография. - Волгоград.: Принт, 2005. - С. 157. на 2012 г. и плановый период 2013 и 2014 гг. ${ }^{20}$ ) тезисно представлена и налоговая политика.

По нашему мнению, налоговая политика имеет временной аспект ее целеполагания. Мы поддерживаем точку зрения А.А. Горшкова ${ }^{21}$ и И.А. Коростелкиной ${ }^{22}$, об интерференции стратегии и тактики политики, и их не противоречии общей концепции политики.

Разработка налоговой политики, по нашему мнению, действительно должна начинаться с определения общей концепции ее развития. Затем должны формулироваться стратегические ориентиры налоговой политики, ее тактические цели динамического характера и отдельные меры по их достижению, что реализуется через налоговый механизм, воздействуя на изменение налоговой системы (рис. 1).

Концептуальной основой современной налоговой политики является совершенствование налоговой системы с целью гармонизации интересов различных субъектов налоговых отношений для обеспечения социально-экономического развития страны.

Стратегические ориентиры налоговой политики, на наш взгляд, представляют собой долговременные, наиболее важные установки органов власти в отношении развития налоговой системы.

Стратегические ориентиры налоговой политики определяют тактические цели динамического характера.

\footnotetext{
20 Основные направления бюджетной политики на 2012 г. и плановый период 2013 и 2014 гг.» (утв. Минфином РФ). Документ опубликован не был. Доступ из справочно-правовой системы «КонсультантПлюс».

${ }^{21}$ Гориков А.А. Проблемы безопасности региональной бюджетной политики: научное издание. - Волгоград: Нижне-Волжское книжное издательство, 2002. - С. 7.

${ }^{22}$ Коростелкина И.А. Концепция формирования многоуровневой налоговой политики // Международный бухгалтерский учет. - 2012. - № 41. - С. 51-59.
} 
Налоговое администрирование

Под тактическими целями стоит понимать приоритеты государственной налоговой политики, образ желаемого будущего в конкретном финансовом периоде, идеальный результат к которому стремятся политические субъекты.
Между приоритетами и мерами налоговой политики существует взаимовлияние. С одной стороны приоритеты налоговой политики предопределяют используемые меры, с другой - меры налоговой политики определяют количественные и качествен-

Рис. 1. Организационная схема осуществления налоговой политики государства

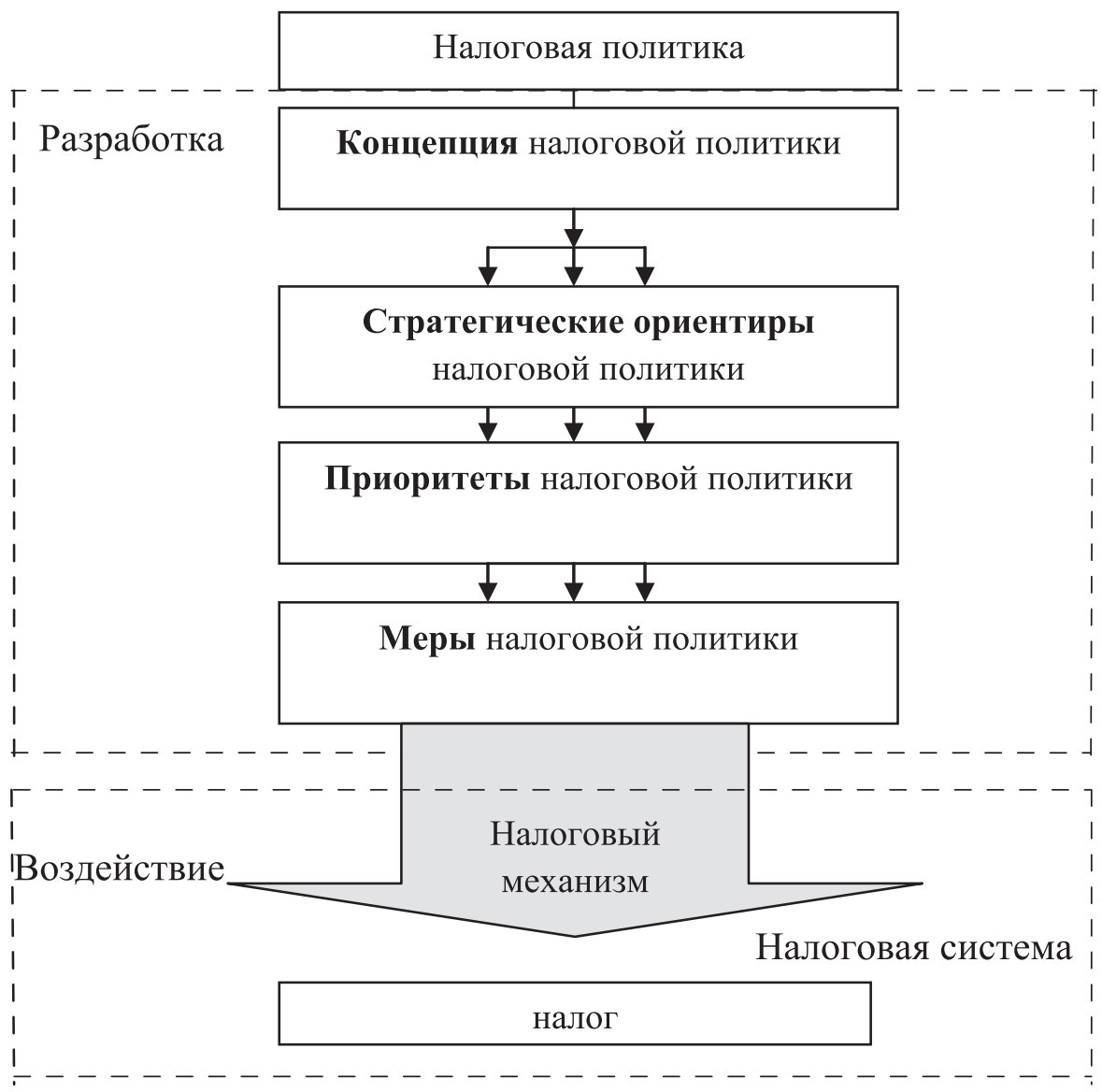

Составлено автором

Меры налоговой политики государства это способ достижения политических целей, поэтому они носят служебный характер, «подчиняются» приоритетам и их обслуживают. Меры налоговой политики являются конкретными инструментами влияния ее субъектов на налоговую систему. Одна и та же целевая установка может достигаться разными мерами. ные характеристики результатов реализации приоритетов политики.

Существующие стратегические ориентиры налоговой политики, устанавливают границы возможного воздействия ее субъектов на налоговую систему государства.

В этой связи представляется целесообразным исследовать историю становления и развития стратегических 


\section{Налоги и налогообложение - №4(106) 2013}

ориентиров государственной налоговой политики России.

Возникновение налогов непосредственно связано с возникновением и становлением финансов, когда формирование и использование бюджета стало носить системный характер и, следовательно, возникла необходимость в наличии доходов, получение которых носило бы постоянный характер.

Прообразы различных налогов и элементов налогообложения известны с глубокой древности, но представляется, что основной предпосылкой формирования той или иной налоговой системы можно считать не просто возникновение государственности, а отделение казны государства (фиск) от казны государя ${ }^{23}$.

Изучив стратегические ориентиры государственной налоговой политики за период с 988 по 1999 гг., можно сказать, что фактически они сводились к финансированию общественных потребностей за счет экономических пожертвований каждого члена общества (рис. 2).
До 988 г. основными видами налогов являлись дани (подати) и оброки. Уплачивались они натурой, чаще всего медом и даже мечами. В основном в этот период налоги устанавливались по случаю войн и походов.

После завоевания Руси Золотой Ордой на основе переписи населения, проведенной в 1257-1259 гг,, также осуществлялось взимание дани.

До середины XVIII в. государственные сборы именовались податями.

Быстрый рост государственных расходов и переход Российской империи от натурального крепостного хозяйства к денежному во второй половине XIX в. способствовали широкому развитию налогообложения. В то время налоги понимались как «экономические пожертвования граждан или подданных, которые государство или иные общественные группы, в силу того что они являются представителями общества, взимают легальным путем и законным способом из их частных имуществ для удов-

Рис. 2. Эволючия стратегических ориентиров государственной налоговой политики за период с 988 г. по 1999 г.

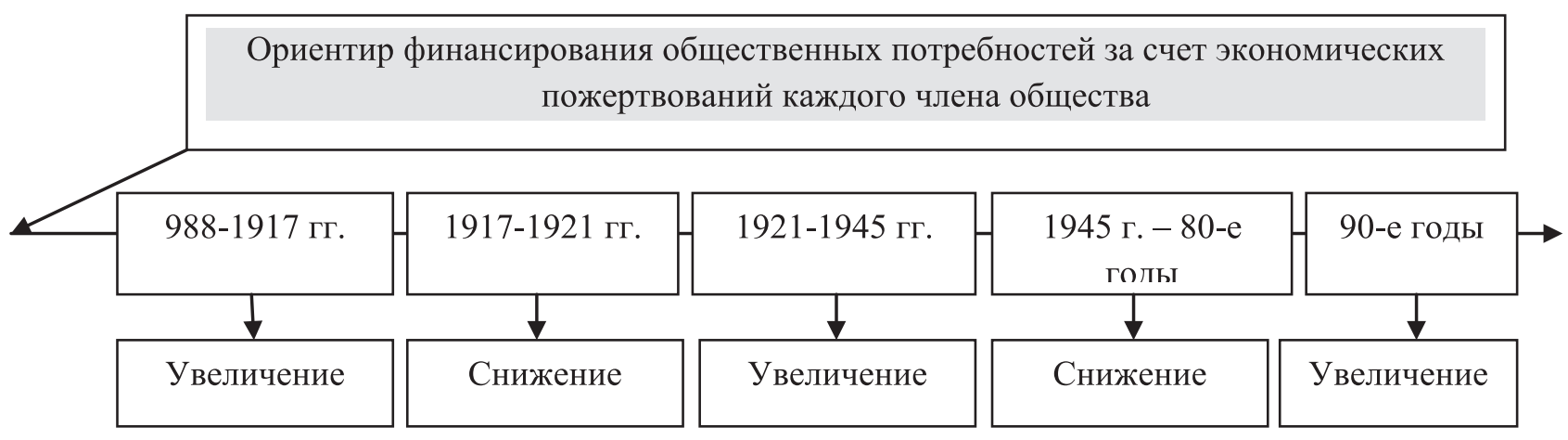

Составлено автором

${ }^{23}$ Кузьмин И.Ю. Некоторые особенности налогообложения за рубежом: история и современность // Аудиторские ведомости. - 2008. - №1. - Доступ из справочно-правовой системы «КонсультантПлюс». 
летворения необходимых общественных потребностей и вызываемых ими издержек» ${ }^{24}$.

В послереволюционный период, начиная с октября 1917 г. и до окончания военного коммунизма, действие всех налогов в России было приостановлено, а податный аппарат полностью расформирован. В это время налоговая политика государства фактически сводилась лишь к принудительному взиманию натурального сбора с крестьянства. Характерной чертой этого периода стала трудовая повинность, которую можно рассматривать как своеобразный трудовой налог.

С поворотом к новой экономической политике, провозглашенной в марте - мае 1921 г,, начался процесс поэтапного восстановления финансовой системы государства и возникла необходимость вернуть отмененные фискальные институты. Создание новой налоговой системы началось с предоставления крестьянству права реализации на рынке излишков сельскохозяйственной продукции, оставшихся после уплаты продналога.

В течение 1923 г. была проведена реформа обложения крестьянства и установлен единый сельскохозяйственный налог, введены промысловый и подоходный налоги, налог на сверхприбыль, налог с наследств и дарений, гербовый сбор.

Послевоенный период в Союзе Советских Социалистических Республик (далее СССР) характеризовался постепенным сворачиванием налогообложения и заменой налогов иными доходными источниками. Основным же налоговым платежом того времени являлся налог с оборота, поступления от которого составили в 1954 г. около 41\% в составе доходной части бюджета.

В 60-е гг. в стране большую популярность получила идея безналогового общества, отри-

\footnotetext{
${ }^{24}$ Борисов А.М. «Краеугольный камень» истории налогообложения // Налоги (журнал). - 2009. - № 2. - Доступ из справочно-правовой системы «КонсультантПлюс».
}

цание налогов становится составной частью государственной экономической политики. Существенным шагом в направлении полной ликвидации налогообложения в стране стала отмена налога с заработной платы. В этот период основная часть доходов государственных предприятий подлежала централизованному перераспределению, изъятию по распоряжению органов государственного управления и зачислению в централизованные денежные фонды. Поэтому государственные предприятия помимо налогов имели обязанность вносить в бюджет и неналоговые платежи. Высокий уровень обобществления собственности в экономике практически полностью исключал возможность возникновения противоречий между интересами государства в целом и интересом отдельного хозяйствующего субъекта по поводу уплаты налогов. В отношении же граждан сохранялась обязанность по уплате некоторых налогов, например подоходного налога или налога на холостяков, одиноких и малосемейных граждан. Порядок их уплаты основывался на удержании сумм налога у источника выплаты.

Налоговая политика России в 70-80-е гг. являлась пассивным инерционным инструментом мобилизации доходов в бюджет страны. Налоги составляли 8 - 9\% общей суммы государственных доходов ${ }^{25}$. Фактически налогообложение сохранялось, но не оказывало существенного влияния на доходы бюджетов.

К концу 1991 г. потребность в полноценном механизме налогообложения стала очевидной. После распада СССР входившие в него ранее республики образовали национальные налоговые системы, что отразилось на доходах бюджета.

Государственная налоговая политика 90-х гг. строилась на максимальном рас-

\footnotetext{
${ }^{25}$ Борисов А.М. «Краеугольный камень» истории налогообложения // Налоги (журнал). - 2009. - № 2. - Доступ из справочно-правовой системы «КонсультантПлюс».
} 


\section{Налоги и налогообложение - №4(106) • 2013}

ширении налоговой базы, поэтому налоговая система включила около 50 видов налогов. К числу основных относились: налог на добавленную стоимость, акцизы на отдельные группы и виды товаров, налог на доходы банков, налог на доходы от страховой деятельности, налог с биржевой деятельности, налог на доходы от операций с ценными бумагами, таможенная пошлина, налог на прибыль (подоходный налог) с предприятий, подоходный налог с физических лиц ${ }^{26}$.

Наличие такого числа налогов в стране привело к нестабильности всей хозяйственной системы, к криминализации экономики, массовому бегству капиталов за границу, отсутствию иностранных инвестиций, что в конечном итоге сказалось на снижении конкурентоспособности страны ${ }^{27}$.

В период с 2000-2007 г. произошла смена стратегических ориентиров государствен- ной налоговой политики. Руководством страны в качестве безусловных требований к налоговой политики были выдвинуты развитие экономической активности субъектов налоговых отношений и ликвидация теневого сектора экономики (рис. 3).

Правительство предпринимает усилия по реформированию налоговой системы России, которые находят отражение в Программе социально-экономического развития России на среднесрочную перспективу (2002-2004 гг.).

Меры реформирования были направлены на снижение избыточной налоговой нагрузки, создающей стимулы к уклонению от уплаты налогов; ослабление фискальных интересов государства в пользу стимулирующей функции налога; снижение неравномерности распределения налоговой нагрузки; сокращение количества и изменение направленности налоговых льгот.

Рис. 3. Эволющчия стратегических ориентиров государственной налоговой политики за период с 2000 г. по 2007 г.

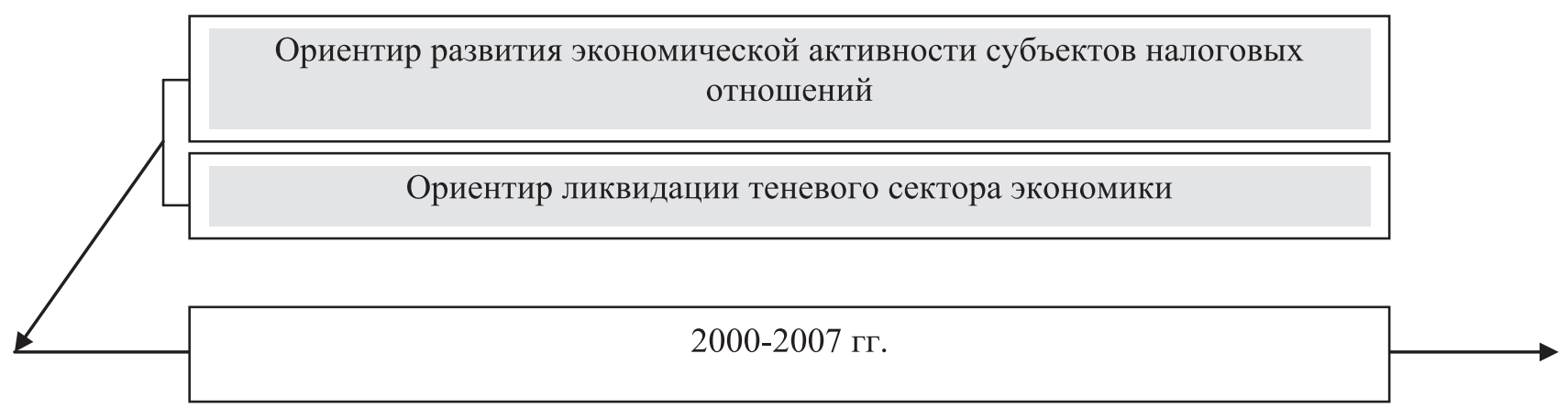

Оптимизация налоговой нагрузки;

Упрощение налоговой системы;

Совершенствование налогового администрирования

${ }^{26}$ Щепотьев А.В., Рожок А.П. Налогообложение

Составлено автором в России: исторический аспект // Аудиторские ведомости. - 2010. - № 9. - С. 68-78.

${ }^{27}$ Моисеенко М.A. Основные направления налоговой политики России // Финансы. - 2010. - № 1. - С. 27 - 29. 
В 2000-2007 гг. произошли следующие принципиальные изменения:

- упразднены «оборотные» налоги и налог с продаж, а также некоторые другие неэффективные налоги, что обеспечило заметное упрощение налоговой системы;

- введен единый социальный налог вместо имевшихся ранее самостоятельных отчислений в государственные социальные внебюджетные фонды с существенно меньшей ставкой и возможностью снижения относительной суммы налога при увеличении размера выплат наемным работникам;

- снижены налоговые ставки по налогу на доходы физических лиц и налогу на прибыль организаций, что, в конечном счете, привело не к снижению, а к росту поступлений по этим налогам;

- введен принципиально новый порядок исчисления налога на прибыль, соответствующий системам налогообложения, применяющимся в международной практике;

- упрощен и облегчен режим налогообложения малого бизнеса и сельскохозяйственных товаропроизводителей за счет введения трех специальных налоговых режимов;

- начата реформа имущественного налогообложения, предусматривающая уменьшение числа объектов налогообложения по налогу на имущество ор- ганизаций и новую систему земельного налога, ориентированную на кадастровую стоимость земельных участков;

- обеспечено более равномерное распределение налоговой нагрузки на всех налогоплательщиков;

- улучшилось налоговое администрирование, что привело к заметному росту собираемости налоговых платежей ${ }^{28}$.

С 2008 г. и по настоящее время в российской налоговой политике можно выделить следующие стратегические ориентиры: 1) обеспечения наполняемости бюджетов; 2) оптимальной налоговой нагрузки хозяйствующих субъектов; 3) обеспечения модернизации экономики; 4) качественного налогового администрирования (рис. 4).

Стратегический ориентир обеспечения наполняемости бюджетов, начиная с 2008 г. остается неизменным, поскольку налоговые доходы бюджетов в большей степени определяют его расходы. Однако, в 2009-2010 гг. обеспечение достаточного объема доходов происходило в условиях противодействия негативным эффектам экономического кризиса, когда многочисленные антикризисные меры в сфере налогообложения привели к существенному сокращению бюджетных доходов.

Так, в 2009 г. были введены антикризисные меры стимулирования деятельности организаций:

- снижена ставка налога на прибыль организаций до $20 \%$;

\footnotetext{
${ }^{28}$ Мандрощенко O.B. Налоговая система и ее влияние на развитие инвестиционной деятельности // Международный бухгалтерский учет. - 2012. - № 45. - C. $62-68$.
} 


\section{Налоги и налогообложение - №4(106)•2013}

Рис. 4. Эволючия стратегических ориентиров государственной налоговой политики за период с 2008 г. по 2013 г.

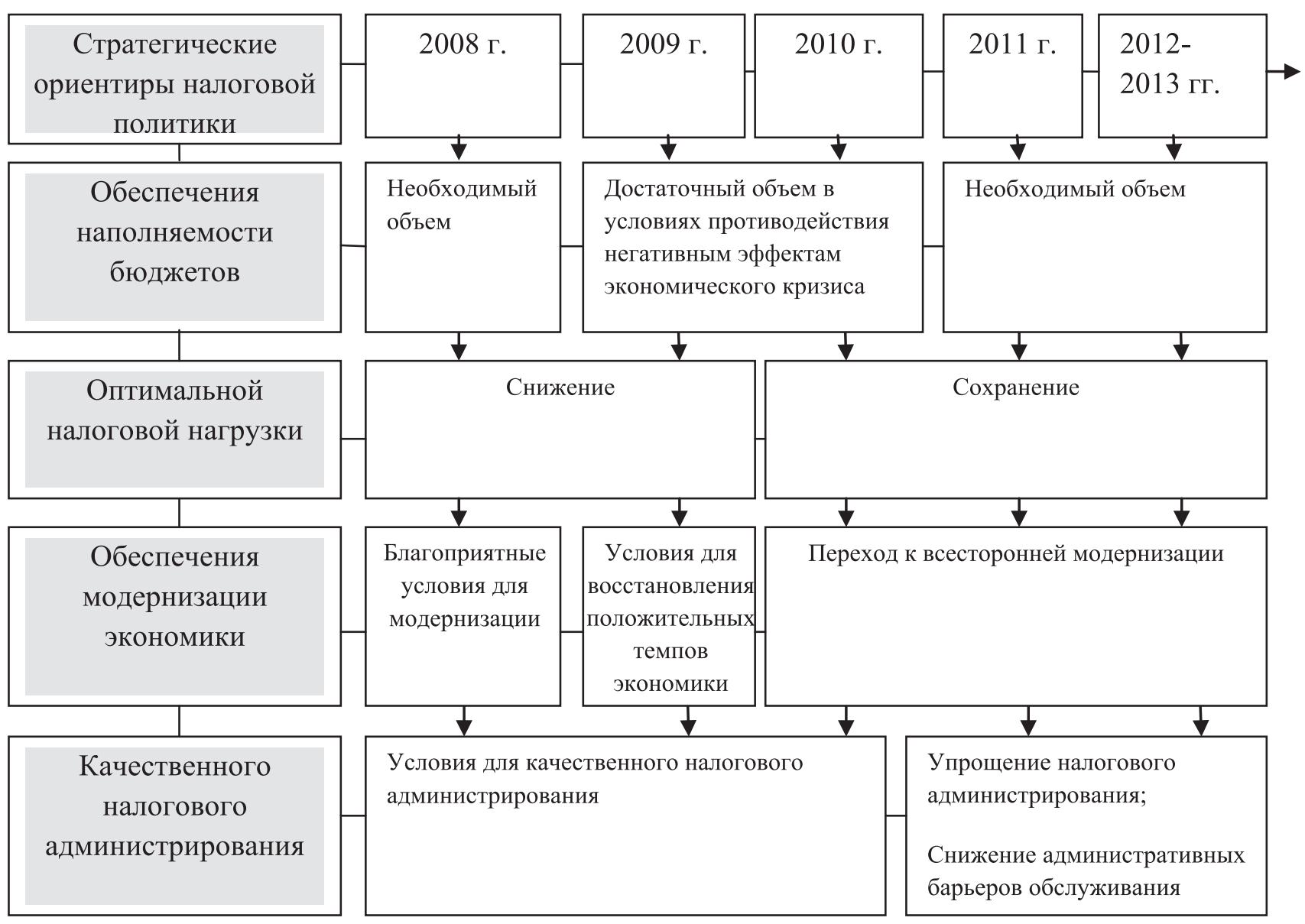

Составлено автором по: Бюджетное послание Президента РФ Федеральному собранию РФ 23.06.2008 г. на период 2009-2011гг. URL: http://президент.pф/acts/508 (дата обращения 12.05.11); Основные направления налоговой политики на 2009 г. и на плановый период 2010 и 2011 гг. (одобрено Правительством РФ 26.05.2008). Документ в данном виде опубликован не был. Доступ из справочно-правовой системы «КонсультантПлюс»; Бюджетное послание Президента РФ Федеральному собранию РФ 25.05 .2009 г. на период 2010-2012 гг. URL: http://президент.pф/acts/2042 (дата обращения 13.05.11); Основные направления налоговой политики РФ на 2010 г. и на плановый период 2011 и 2012 гг. (одобрено Правительством РФ 25.05.2009). Документ в данном виде опубликован не был. Доступ из справочно-правовой системы «КонсультантПлюс»; Программа антикризисных мер Правительства РФ на 2009 г. (утв. Правительством РФ) // Российская газета. - № 48, 20.03.2009; Основные направления налоговой политики РФ на 2011 г. и на плановый период 2012 и 2013 гг. (одобрено Правительством РФ 20.05.2010). Документ в данном виде опубликован не был. Доступ из справочно-правовой системы «КонсультантПлюс»; Бюджетное послание Президента РФ Федеральному собранию РФ 29.06.2010 на период 2011-2013 гг. URL: http://президент.pф/acts/8192 (дата обращения 12.05.11); Подкопаев M.B. Основные налоговые изменения, которые нужно учесть в 2011 году // Актуальные вопросы бухгалтерского учета и налогообложения. 2011. - № 1. - С. 11-22; Трушищына А.Ю. Изменения в налоговом законодательстве с 2011 года // Бухгалтер и закон. - 2011. - № 4. - С. 6-13; Лермонтов Ю. Налоговая политика на 20112013 годы // Аудит и налогообложение. - 2011. - № 1. - С. 2-10. 
- увеличена «амортизационная премия» по налогу на прибыль организаций;

- $\quad$ введены налоговые льготы по налогу на добычу полезных ископаемых при добыче нефти, снижены его ставки;

- увеличена предельная величина процентов по долговым обязательствам, которая может быть учтена в расходах для целей налогообложения прибыли;

- увеличен размер взносов по договорам добровольного личного страхования, предусматривающим оплату страховщиками медицинских расходов застрахованных работников, которые включаются в состав расходов в размере с $3 \%$ до $6 \%$ и т.д.

Стратегический ориентир оптимальной налоговой нагрузки в 2008, 2009 и 2010 гг. характеризовался снижением уровня нагрузки.

В 2008 г. введены следующие меры по снижению налоговой нагрузки:

- введены налоговые каникулы на новых месторождениях, расположенных на континентальном шельфе, во внутренних морских водах и в территориальном море РФ;

- установлен предел социального налогового вычета по налогу на доходы физических лиц (далее - НДФЛ) 100 тыс. руб.;

- установлена возможность получения вычета по НДФЛ на благотворительность;

- coциальные налоговые вычеты по НДФЛ распространены на опекунов и попечителей и т.д.

В 2009 г.:

- установлен предел социального налогового вычета по НДФЛ 120 тыс. руб.;

- увеличен размер имущественного вычета по НДФЛ на покупку жилья до 2 000000 руб.;

- увеличены размеры стандартных налоговых вычетов по НДФЛ. Сумма до- хода, при котором налогоплательщик имеет право на стандартный налоговый вычет в размере 400 рублей, увеличена с 20000 рублей до 40000 рублей. Для налогоплательщиков, на обеспечении которых находится ребенок (дети), стандартный налоговый вычет с 600 рублей за каждый месяц налогового периода увеличен до 1000 рублей, а сумма дохода, при которой налогоплательщик вправе воспользоваться налоговым вычетом на ребенка, с 40000 рублей, начисленных нарастающим итогом с начала налогового периода, увеличена до 280000 рублей;

- введены «налоговые каникулы» по налогу на добычу полезных ископаемых на нефть, то есть применение нулевой налоговой ставки при добыче на некоторых участках недр (на территориях севернее Северного полярного круга, Ненецкого автономного округа, полуострове Ямал в Ямало-Ненецком автономном округе, континентальном шельфе Российской Федерации, Азовском и Каспийском морях);

- по упрощенной системе налогообложения (далее - УСНО) и системе налогообложения для сельскохозяйственных товаропроизводителей отменены ограничения на перенос убытка, полученного по итогам предыдущих налоговых периодов, на будущие налоговые периоды и т.д.

В 2010 г.:

- отменен единый социальный налог и введены страховые взносы на обязательное пенсионное, медицинское и социальное страхование;

- снижены пределы размера доходов, дающих право для перехода на УСНО.

В 2011-2013 гг. налоговая нагрузка не снижалась. 


\section{Налоги и налогообложение - №4(106) • 2013}

Стратегический ориентир обеспечения модернизации экономики в 2008 г. был связан с созданием условий для ее осуществления. Так, в 2008 г. установлено освобождение от уплаты налогом на добавленную стоимость (далее - НДС) при передаче исключительных прав на основные виды интеллектуальной собственности; предусмотрено освобождение от уплаты НДС научно-исследовательских, опытноконструкторских и технологических работ независимо от источников их оплаты; введён повышающий коэффициент амортизации для основных средств, используемых исключительно для научно-технической деятельности.

В 2009 г. в связи с кризисными явлениями в экономике ориентир обеспечения ее модернизации сводился к восстановлению положительных темпов развития страны.

В 2010-2013 гг. данный ориентир трактуется как переход к всесторонней модернизации. В эти годы для выполнения данного требования, предъявляемого государством к налоговой политике, было реализовано множество мер, однако, думается, что переход к всесторонней модернизации экономики все еще продолжается.

Так, в 2010 г. было уточнено условие перехода на УСНО некоторых инновационных организаций, даже если доля участия в них других организаций составляет более 25\%. В 2011 г. сокращен перечень документов, необходимых для подтверждения применения нулевой ставки НДС при экспортных операциях; переданы полномочия по принятию решения о предоставлении инвестиционного налогового кредита по налогу на прибыль и налогу на имущество организаций субъектам РФ и т.д.

Стратегический ориентир качественного налогового администрирования в 2008 г. был связан с созданием условий его осу- ществления. Так, в 2008 г. были уточнены практически все формы отчетности по налогам. В 2010 г. были проиндексированы санкции за налоговые правонарушения; изменены компетенции органов, уполномоченных вести следствие по налоговым преступлениям; разработан и введен в действие механизм по уплате процентов за незаконное приостановление операций по счетам налогоплательщика; установлен запрет на истребование документов ранее истребованных.

В 2011-2013 гг. в рамках рассматриваемого ориентира предусмотрено упрощение налогового администрирования и повышение качества обслуживания налогоплательщиков. Разработаны и введены в действия интерактивные сервисы для налогоплательщиков, утвержден ряд стандартов по их облуживанию.

Таким образом, изучив эволюцию стратегических ориентиров государственной налоговой политики можно выделить экономические, правовые, политические и социальные факторы их формирования.

К экономическим факторам относятся: преобладающая в стране форма собственности; наличие кризисных явлений в экономике; макроэкономические показатели (ВВП, платежный баланс, государственный долг и т.д.); экономическая активность хозяйствующих субъектов и т.д. К правым факторам - развитость отраслевого законодательства, его стабильность и непротиворечивость. К политическим - смена власти, характер политического режима, высокий уровень политической конкуренции и т.д. К социальным - качество рабочей силы, качество жизни населения (доходы населения, экономически справедливая оценка труда, социальные гарантии, социальная поддержка и т. д.), научно-технический и образовательный потенциал. 
Исходя из выделенных факторов, можно предположить, что в среднесрочной перспективе формирование фискального пространства будет происходить под влиянием действующей совокупности стратегических ориентиров налоговой политики, содержание которых может меняться под воздействием объективных экономических процессов.

\section{Библиография:}

1. Амосов А.И. Промышленная политика и перелив капитала // Экономист. - 2004. - № 10. - С. 12-16.

2. Андросов В.В. Карпунина Е.К. Экономическая политика государства: значение национального российского менталитета // Социально-экономические явления и процессы. - 2010. - № 1. - С. 45-49.

3. Андросов В.В. Экономическая политика государства: вопросы методологии // Социально-экономические явления и процессы. - 2010. - № 2. - С. 8-11;

4. Афонцев С.А. Теоретический анализ формирования экономической политики на национальных и международных политических рынках: автореф. ... д.э.н. - Москва, 2010. - 39 с.

5. Бережной И.В. Государственная экономическая политика обеспечения конкуренции: уровни, проблемы, инструменты // Journal of Economic Regulation = Вопросы регулирования экономики. - 2010. - T. 1. - № 1. - C. 23-32.

6. Борисов А.М. «Краеугольный камень» истории налогообложения // Налоги (журнал). - 2009. - № 2. Доступ из справочно-правовой системы «КонсультантПлюс».

7. Буланова Е.А. Политика и стратегия в механизме государственного регу- лирования социально-экономических процессов // Вестник Чувашского университета. - 2006. - № 3. - С. 143-153.

8. Бюджетное послание Федеральному Собранию «О бюджетной политике на 2001 г.» 31 мая 2000 г. URL.: http:// openbudget.karelia.ru/budposl_pres2001. html (дата обращения 25.04.2013).

9. Васильева М.В., Лукьянова А.В. Императивы бюджетной политики: региональный и муниципальный аспекты: монография. - Волгоград.: Принт, 2005. $-475 \mathrm{c}$.

10. Горшков А.А. Проблемы безопасности региональной бюджетной политики: научное издание. - Волгоград: НижнеВолжское книжное издательство, 2002. $-71 \mathrm{c}$.

11. Кейнс Дж. М. Общая теория занятости, процента и денег. - М.: Прогресс, 1978. -236 c.

12. Ковалева Т.М., Барулин С.В. Бюджет и бюджетная политика в РФ: научное издание. - М.: КНОРУС, 2006. - 208 с.

13. Коростелкина И.А. Концепция формирования многоуровневой налоговой политики // Международный бухгалтерский учет. - 2012. - № 41. - С. 51-59.

14. Коуэн Р. Зависимость от предшествующей траектории развития, причинная связь и экономическая политика // Terra Economicus. - 2004. - T. 2. - № 4. C. $10-29$.

15. Кузьмин И.Ю. Некоторые особенности налогообложения за рубежом: история и современность // Аудиторские ведомости. - 2008. - №1. - Доступ из справочно-правовой системы «КонсультантПлюс».

16. Лоскутов В.Г. Державная экономическая политика императивы выживаемости России как национального государства // Вестник Тамбовского 
университета. Серия: Гуманитарные науки. - 2010. - Т. 81. - № 1. - С. 9-14.

17. Мандрощенко О.В. Налоговая система и ее влияние на развитие инвестиционной деятельности // Международный бухгалтерский учет. - 2012. - № 45. - С. 62-68.

18. Моисеенко М.А. Основные направления налоговой политики России // Финансы. - 2010. - № 1. - С. 27-29.

19. Ойкен В. Основы национальной экономии: научное издание. - М.: ДиректМедиа, 2007. - 326 с.

20. Основные направления бюджетной политики на 2012 г. и плановый период 2013 и 2014 гг.» (утв. Минфином РФ). Документ опубликован не был. Доступ из справочно-правовой системы «КонсультантПлюс».

21. Пашков А.В. Экономическая политика: понятие и содержание // Исторические, философские, политические науки, культурология и искусствоведение. Вопросы теории и практики. - 2012. - . № 5-2. - С. 133-138.

22. Розанова Н.М. Экономическая политика России и конкуренция: есть ли точки соприкосновения // Terra Economicus. 2005. - Т. 3. - № 1. - С. 43-61.

23. Рыбаков Ф.Ф. Экономическая политика: теоретические основы и опыт преподавания // Вестник Санкт-Петербургского университета. Серия 5: Экономика. 2009. - № 1. - С. 144-150.

24. Словарь современной экономической теории Макмиллана / под ред. Пирс В.А. - М.:, Инфра-М, 2003. - 608 с.

25. Щепотьев А.В., Рожок А.П. Налогообложение в России: исторический аспект // Аудиторские ведомости. - 2010. - № 9. - С. 68-78.

26. Яременко Ю.В. Экономический рост. Структурная политика // Проблемы прогнозирования. - 2001. - № 1. - С. 6-14.

\section{References (transliteration):}

1. Amosov A.I. Promyshlennaya politika i pereliv kapitala // Ekonomist. - 2004. - № 10. S. 12-16.

2. Androsov V.V. Karpunina E.K. Ekonomi cheskaya politika gosudarstva: znachenie nacional'nogo rossiyskogo mentaliteta // Social'no-ekonomicheskie yavleniya i processy. - 2010. - № 1. - S. 45-49.

3. Androsov V.V. Ekonomicheskaya politika gosudarstva: voprosy metodologii // Social'no-ekonomicheskie yavleniya i processy. - 2010. - № 2. - S. 8-11;

4. Afoncev S.A. Teoreticheskiy analiz formirovaniya ekonomicheskoy politiki na nacional'nyh i mezhdunarodnyh politicheskih rynkah: avtoref. ... d.e.n. Moskva, 2010. - 39 s.

5. Berezhnoy I.V. Gosudarstvennaya ekonomicheskaya politika obespecheniya konkurencii: urovni, problemy, instrumenty // Journal of Economic Regulation = Voprosy regulirovaniya ekonomiki. - 2010. - T. 1. - № 1. - S. 23-32.

6. Borisov A.M. «Kraeugol'nyy kamen'» istorii nalogooblozheniya // Nalogi (zhurnal). - 2009. - № 2. - Dostup iz spravochnopravovoy sistemy «Konsul'tantPlyus».

7. Bulanova E.A. Politika i strategiya v mehanizme gosudarstvennogo regulirovaniya social'no-ekonomicheskih processov // Vestnik Chuvashskogo universiteta. - 2006. - № 3. - S. 143-153.

8. Vasil'eva M.V., Luk'yanova A.V. Imperativy byudzhetnoy politiki: regional'nyy i municipal'nyy aspekty: monografiya. Volgograd.: Print, 2005. - 475 s.

9. Gorshkov A.A. Problemy bezopasnosti regional'noy byudzhetnoy politiki: nauchnoe izdanie. - Volgograd: NizhneVolzhskoe knizhnoe izdatel'stvo, 2002. $-71 \mathrm{~s}$. 
10. Keyns Dzh. M. Obschaya teoriya zanyatosti, procenta i deneg. - M.: Progress, 1978. - $236 \mathrm{~s}$.

11. Kovaleva T.M., Barulin S.V. Byudzhet i byudzhetnaya politika v RF: nauchnoe izdanie. - M.: KNORUS, 2006. - 208 s.

12. Korostelkina I.A. Koncepciya formirovaniya mnogourovnevoy nalogovoy politiki // Mezhdunarodnyy buhgalterskiy uchet. 2012. - № 41. - S. 51-59.

13. Kouen R. Zavisimost' ot predshestvuyuschey traektorii razvitiya, prichinnaya svyaz' i ekonomicheskaya politika // Terra Economicus. - 2004. - T. 2. - № 4. S. 10-29.

14. Kuz'min I.Yu. Nekotorye osobennosti nalogooblozheniya za rubezhom: istoriya $\mathrm{i}$ sovremennost' // Auditorskie vedomosti. - 2008. - №1. - Dostup iz spravochnopravovoy sistemy «Konsul'tantPlyus».

15. Loskutov V.G. Derzhavnaya ekonomicheskaya politika imperativy vyzhivaemosti Rossii kak nacional'nogo gosudarstva // Vestnik Tambovskogo universiteta. Seriya: Gumanitarnye nauki. - 2010. - T. 81. № 1. - S. 9-14.

16. Mandroschenko O.V. Nalogovaya sistema i ee vliyanie na razvitie investicionnoy deyatel'nosti // Mezhdunarodnyy buhgalterskiy uchet. - 2012. - № 45. - S. 62-68.

17. Moiseenko M.A. Osnovnye napravleniya nalogovoy politiki Rossii // Finansy. - 2010. - № 1. - S. 27-29.

18. Oyken V. Osnovy nacional'noy ekonomii: nauchnoe izdanie. - M.: Direkt-Media, 2007. - 326 s.

19. Pashkov A.V. Ekonomicheskaya politika: ponyatie i soderzhanie // Istoricheskie, filosofskie, politicheskie nauki, kul'turologiya i iskusstvovedenie. Voprosy teorii i praktiki. - 2012. - . № 5-2. - S. 133-138.

20. Rozanova N.M. Ekonomicheskaya politika Rossii i konkurenciya: est' li tochki soprikosnoveniya // Terra Economicus. 2005. - T. 3. - № 1. - S. 43-61.

21. Rybakov F.F. Ekonomicheskaya politika: teoreticheskie osnovy i opyt prepodavaniya // Vestnik Sankt-Peterburgskogo universiteta. Seriya 5: Ekonomika. - 2009. № 1. - S. 144-150.

22. Schepot'ev A.V., Rozhok A.P. Nalogooblozhenie v Rossii: istoricheskiy aspekt // Auditorskie vedomosti. - 2010. - № 9. - S. 68-78.

23. Yaremenko Yu.V. Ekonomicheskiy rost. Strukturnaya politika // Problemy prognozirovaniya. - 2001. - № 1. - S. 6-14. 